\title{
Use of marine sponges as stress indicators in marine ecosystems at Algeciras Bay (southern Iberian Peninsula)
}

\author{
J. L. Carballo*, S. A. Naranjo, J. C. García-Gómez \\ Laboratorio de Biología Marina, Dpto de Fisiología y Biología Animal, Facultad de Bíología, Apdo 1095, \\ E-41080 Sevilla, Spain
}

\begin{abstract}
Infralittoral sponge fauna was studied as part of a multidisciplinary investigation of benthic communities in Algeciras Bay. On a monthly basis over 1 year, a series of environmental variables were measured (hydrodynamism, silting, suspended solids, dissolved organic matter, \% organic matter in silt). The only abiotic variable that was significantly correlated with beta diversity was hydrodynamism, with a linear regression model between the 2 variables showing a correlation coefficient of 0.66 . The distributional pattern of the sponges (based on the relative abundance matrix) was correlated with the environmental variables by matching sample similarities using the Spearman rank correlation, thus showing that the variable combination that best explains the patterns of distribution is hydrodynamism/organic matter in silt $\left(\rho_{\mathrm{s}}=0.6\right)$. Of the species considered, Phorbas fictitius, Cliona celata, Cliona viridis, Crella elegans, Oscarella lobularis, Dysidea fragilis were among those showing the greatest adaptive plasticity in their relationship to environmental variables, depth, and selection by substrate, and are categorized as eurytopic species present in areas subject to great environmental stress. Other species such as Phorbas tenacior, Reniera fulva, Reniera mucosa, Cliona rhodensis proved to be much more sensitive to these variables, and were categorized as stenotopic species, indicators of normal conditions. Due to the particular environmental conditions where it is located, Mycale micracanthoxea was categorized as a good indicator species in port environments. Others such as Dysidea avara, Halichondria bowerbanki or Crella elegans presented morphological differentiations which have permitted them to adapt to sedimentary environments.
\end{abstract}

KEY WORDS: Sponge communities - Abiotic environment - Bioindicator species - Stress · Port environments

\section{INTRODUCTION}

Sponges are dominant members of many benthic communities and, from the autoecological point of view, individual sponge species can have very specific requirements for substrate quality, food particles, light, current regime (Reiswig 1971, Wilkinson \& Vacelet 1979). Moreover, sponges are strongly associated with the abiotic environment and are therefore very sensitive to environmental stress, which is why some authors have suggested them as useful tools for environmental monitoring (Alcolado 1978, Alcolado \& Her-

·E-mail: luiscar@cica.es rera 1987. Muricy 1989, 1991, Carballo et al. 1994). There is now widespread recognition that chemical monitoring alone is not enough and that pollution is essentially a biological phenomenon because its impact is on living organisms (Wright et al. 1994). Stress operates on individual organisms, but its effects may be recognised at population and ecosystem levels. Stress induces qualitative and quantitative changes in the structure of communities which can usually be assessed by analysing diversity, relative abundance (Hawkins et al. 1994).

Sponge communities can provide us with important information about the temporal behaviour of the abiotic factors which affect them; hence, it is feasible to interpret the environment by studying this ecological 
structure (Alcolado \& Herrera 1987). However, the use of sponges in monitoring studies is still limited by the little knowledge available on biotic and abiotic factors affecting the structure of these communities.

Algeciras Bay, Spain, is characterised by a great patchwork of small homogeneous environments, and along its $30 \mathrm{~km}$ coastline there are important industrial areas with chemical industries, refineries, thermal power plants, ironworks, paper mills, and shipyards, along with a major port. All of this activity may in some way influence the sessile benthic organisms found in the bay. The amount of urban sewage corresponds to a population of approximately 205000 inhabitants; industrial contamination corresponds to 150000 inhabitants (Wait et al, 1990). Into the bay's center flow 2 rivers, the Palmones and the Guadarranque, each with an amount of sewage corresponding to 15000 inhabitants, and industrial contamination corresponding to 15000 in habitants for the former and 2500 for the latter (Wait et al. 1990).

The composition and abundance of the benthic communities situated in Algeciras Bay are conditioned by their level of adaptation to general environmental factors and to factors of a more local character, such as organic material, contamination, and deep water movement. These physico-chemical factors generally have a great influence on the distribution of the majority of filtering sessile invertebrates. In this sense, we have related the distnbution patterns of sponges to a series of abiotic variables (water movement, suspended solids), which are considered by the majority of authors as responsible, along with a series of other biotic factors (type of substrate, epibiotic relationships, symbiosis, etc.), for the presence/absence of a species in a given habitat (Sará \& Vacelet 1973, Wilkinson \& Cheshire 1989)

\section{MATERIAL AND METHODS}

The sampling stations inside Algeciras Bay were chosen on the basis of the heterogeneity of the environment at depths between 5 and $30 \mathrm{~m}$. In this way, stations were set up at the main port constructions, shipyards, piers, natural rock formations, etc. Fig. 1 shows the various sampling areas. The specimens were collected by SCUBA diving along permanent transects in order to ensure sampling reproducibility. Each transect (approximately $50 \mathrm{~m}$ long) was sampled at least 4 times a year with a similar immersion time at all the stations (there were no replicates on each occasion). All sponges sighted at a distance of $1 \mathrm{~m}$ at either side of the transects were collected and/or photographed. We used semi-quantitative sampling, which is more appropriate for our subject, and we established abundance codes which permitted us to objectively compare the information obtained at the various sampling stations (Table 1). Coding usually tends to have the effect of normalising data, and subsequent transformation is then unnecessary (Field et al. 1982).

In order to monitor water quality we analysed hydrodynamism, dissolved organic matter, suspended solids, silting and \% organic matter in the silt gathered in collecting bottles (SOM). These parameters were measured on a monthly basis for 1 yr at 8 of the 12 stations. To measure silting and hydrodynamism a set of bottom-mounted frames was placed along the Algeciras Bay littoral, each one having 6 sediment collecting bottles (Moore 1972), which remained for a month at each sampling station (Carballo et al. 1994). To estimate the water movement we used the method of plaster dissolution described by Gambi et al. (1989). The hydrodynamism was calculated in water speed equivalents (V) according to the formula suggested by Bailey-Brock (1979). The suspended solids, dissolved organic matter and SOM (silt which remained in the sediment traps) were measured using methods described by Strickland \& Parsons (1960). All environmental variables were log transformed to normality, the latter confirmed by means of a chi-squared test.

Similarities among the sampling stations were established by means of a classification analysis, using as variables the species present in the established zones. The similarity matrix for the classification was calculated by means of the Bray-Curtis index (Bray \& Curtis 1957). This index was chosen as it does not consider

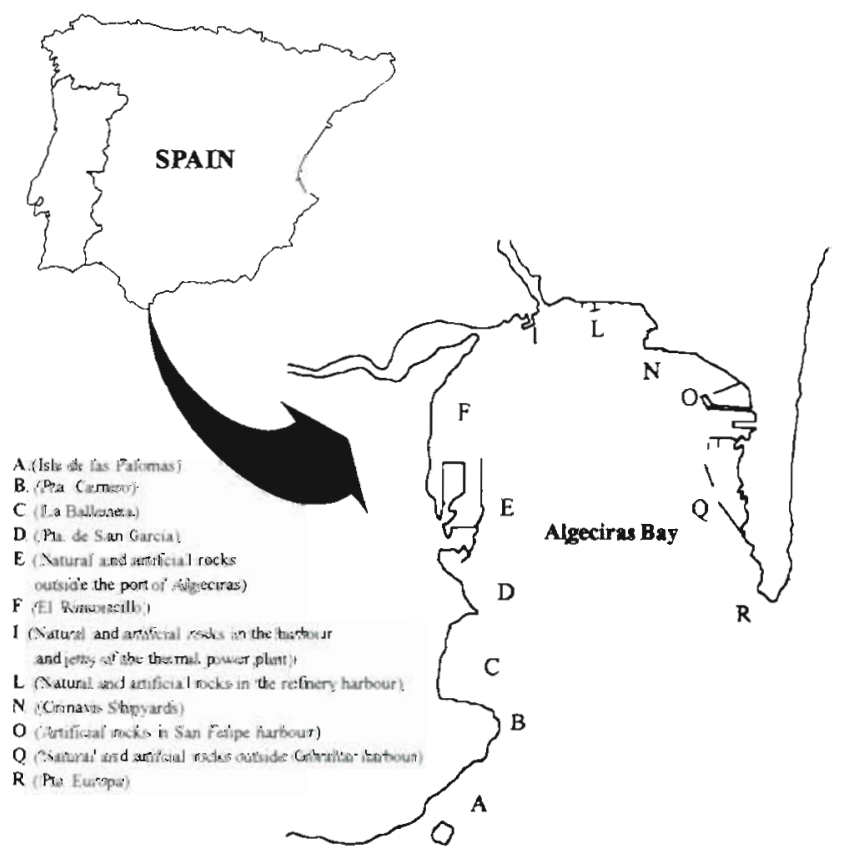

Fig. 1. Location of the sampling stations in the study area 
double absences, frequently found in our data base, in its calculations. The results were then graphically described using dendrograms with the UPGMA ('unweighted pair-group method using centroids') aggregation algorithm (Sneath \& Sokal 1973). The species mainly responsible for the dissimilarity between sampling stations were determined using the computer program SIMPER (Clarke 1993).

The ordination analyses were carried out by means of an MDS ('non-metric multi-dimensional scaling program') based on the similarity matrix between stations. In order to individually relate environmental variables to sampling stations, the letters of the stations, proportional in size to the numerical value of each variable, were superimposed on a 2-dimensional MDS configuration to provide a 'visual correlation' (Field et al. 1982). In this manner we were able to study the influence of different environmental variables on the various areas of study. In addition we carried out a factorial analysis in order to explore the relationship patterns which group the various species together.

The relationship between the abiotic and the biotic variables was studied by means of a correlation and regression analysis, as well as the BIO-ENV program which establishes the relationships between the data and the way in which the biotic and environmental data are linked (Clarke \& Ainsworth 1993).

The software used was PRIMER from Plymouth Marine Laboratory for MDS, SIMPER and BIO-ENV analysis, and Statgraphics for multiple 'box-and-whisker' plots, regressions and factorial analysis.

\section{RESULTS}

\section{Complete data matrix: species composition}

Fig 2 shows the beta diversity $\left(\beta_{w}=\frac{S}{\bar{\alpha}-1}\right)$ (Wilson \& Shmida 1984) for each of the stations sampled, where $S$ is the total number of species recorded in the sampling station, and $\bar{\alpha}$ is the average number of species found within the community samples. The total number of species varied considerably among the different areas. Generally, the main differences occurred between the group of stations situated at the innermost parts of the bay (Stns $E$ to $O$ ) and the group of stations most externally situated (Stns A, B, C, D, Q and R). The maximum values occurred at $\operatorname{Stn} A$ (37 species), and the minimum value was at Stn I (16 species) (Table 1) Similarly, the beta diversity $\left(\beta_{\mathrm{w}}\right)$ values were greatest at Stns A (1.510) and D (1.469).

Table 1 shows the bathymetric distribution range, the substrate type, and the frequency of appearance in a determined enclave. The study of the local distribu-

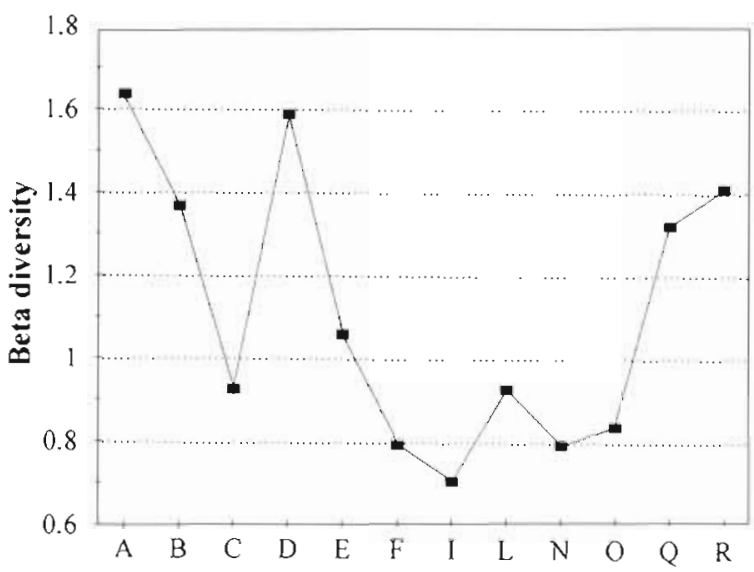

Fig. 2. Beta diversity $\left(\beta_{\mathrm{w}}\right)$ of sponge communities at sampling Stns A to R

tion of the common species showed 3 basic distributional patterns:

- Species found throughout the Bay: Cliona celata, Cliona viridis, Crambe crambe, Crella elegans, Dysidea fragilis, Oscarella lobularis, Phorbas fictitius, Terpios fugax, Suberites domuncula, etc.

- Species distributed mainly at the extremes of the Bay: Acanthella acuta, Cliona rhodensis, Haliclona mucosa, Haliclona fulva, Dyctionella incisa, etc.

- Species found mainly in the centre: Mycale micracanthoxea, Hymedesmia senegalensis, Stylopus dujardini, Haliclona cinerea, etc.

\section{Cluster analysis and MDS}

Fig. 3 shows the result of clustering the stations using the Bray-Curtis index for similarities. Cluster analysis distinguished 2 main groups of sites, which were considered as representing different communities on the basis of semi-quantitative species composition. In the first group (G1) the sites are clearly at the exterior of the bay (Stns A, B, D, Q and R). Within the G1 group the strongest similarity $(76 \%)$ occurs between Stns A and B, which are geographically very close and have a large number of common species. Moreover, there is approximately 68\% similarity between these 2 stations and Stn R.

We can observe 2 subgroups within group $G 2$, one formed by Stns I, L, and N, corresponding to the most internal areas in Algeciras Bay (power plant, refinery and shipyards, respectively), and the other formed by Stns $F, E$, and $C$, corresponding to the Port of Algeciras and its zone of influence ( $E$ and $F$ respectively), as well as a small cove located at the west margin (C). The species found at these 6 stations can generally be considered as cosmopolitan and abundant throughout the bay (Phorbas fictitius, Cliona celata $C$. viridis, Crambe 
Table 1. Complete data matrix. Coded abundances: $0=$ absent; $1=$ present $(1$ or 2 specimens on average per $1 \mathrm{mmersion}$; $2=\mathrm{com}$ mon (between 3 and 5 specimens per immersion); $3=$ very common (an average of more than 6 specimens per immersion) No.: total number of stations at which a species appears; $\bar{\alpha}$ : average number of species found within the community samples $V$ : vertical surfaces; $O$ : overhangs; $H$ : horizontal surfaces; U: under rocks; CC; crevices and cavities; C: small caves; E: epibiont

\begin{tabular}{|c|c|c|c|c|c|c|c|c|c|c|c|c|c|c|c|c|c|}
\hline \multirow[t]{2}{*}{ Taxa } & \multicolumn{12}{|c|}{ Relative abundance at Stn: } & \multirow[t]{2}{*}{ No. } & \multicolumn{4}{|c|}{$\begin{array}{l}\text { Bathymetric distribution and } \\
\text { substrate orientation }\end{array}$} \\
\hline & A & B & $\mathrm{C}$ & $\mathrm{D}$ & $E$ & $F$ & I & $\mathrm{L}$ & $\mathrm{N}$ & 0 & $Q$ & $\mathrm{R}$ & & $0-5 \mathrm{~m}$ & $5-10 \mathrm{~m}$ & $10-20 \mathrm{~m}$ & $20-30 \mathrm{~m}$ \\
\hline 1 Acanthella acuta & 0 & 0 & 0 & 0 & 0 & 0 & 0 & 0 & 0 & 0 & 0 & 2 & 1 & & & 0 & \\
\hline 2 Ciocalapata almae & 0 & 0 & 0 & 1 & 0 & 0 & 0 & 0 & 0 & 0 & 0 & 0 & 1 & & & U & \\
\hline 3 Antho involvens & 1 & 2 & 0 & 0 & 0 & 0 & 1 & 0 & 0 & 0 & 1 & 1 & 5 & & $\mathrm{CC}$ & & $\mathrm{H}, \mathrm{E}$ \\
\hline 4 Aplysilla rosea & 1 & 1 & 2 & 3 & 0 & 0 & 0 & 0 & 0 & 2 & 1 & 1 & 7 & $\mathrm{~V}, \mathrm{U}, \mathrm{O}$ & $\mathrm{O}$ & & \\
\hline 5 Aplysilla sulphurea & 0 & 0 & 0 & 0 & 0 & 0 & 0 & 1 & 0 & 1 & 1 & 1 & 4 & $\mathrm{~V}$ & $\mathrm{U}$ & & $\mathrm{U}$ \\
\hline 6 Axinella damicornis & 1. & 1 & 0 & 0 & 0 & 0 & 0 & 0 & 0 & 0 & 1 & 1 & 4 & & & & $\mathrm{H}$ \\
\hline 7 Batzella inops & 0 & 0 & 0 & 0 & 0 & 0 & 0 & 0 & 0 & 0 & 1 & 0 & 1 & & & $\mathrm{U}$ & \\
\hline 8 Cacospongia mollior & 0 & 1 & 0 & 0 & 0 & 0 & 0 & 0 & 0 & 0 & 0 & 0 & 1 & & $\mathrm{CC}$ & & \\
\hline 9 Cacospongis scalaris & 1 & 1 & 1 & 1 & 2 & 2 & 0 & 0 & 0 & 1 & 1 & 1 & 9 & $\mathrm{O}, \mathrm{V}$ & $\mathrm{CC}, \mathrm{O}, \mathrm{H}$ & $\mathrm{H}, \mathrm{CC}, \mathrm{O}$ & \\
\hline 10 Chalinula fertilis & 0 & 0 & 0 & 1 & 0 & 0 & 0 & 0 & 0 & 0 & 0 & 0 & 1 & U & & & \\
\hline 11 Chalunula nigra & 0 & 0 & 0 & 0 & 0 & 0 & 0 & 0 & 0 & 0 & 1 & 0 & 1 & & & $\mathrm{H}$ & \\
\hline 12 Chondrosia reniformis & 2 & 1 & 0 & 3 & 0 & 1 & 0 & 0 & 0 & 0 & 1 & 1 & 6 & $\mathrm{H}, \mathrm{CC}$ & $\mathrm{V}, \mathrm{H}$ & $\mathrm{O}$ & \\
\hline 13 Clathria coralloides & 0 & 0 & 0 & 1 & 0 & 0 & 0 & 0 & 0 & 0 & 0 & 0 & 1 & $\mathrm{U}$ & & & \\
\hline 14 Cliona celata & 1 & 1 & 1 & 1 & 2 & 1 & 1 & 1 & 1 & 2 & 1 & 1 & 12 & $\mathrm{H}, \mathrm{V}, \mathrm{O}$ & $\mathrm{H}, \mathrm{V}, \mathrm{O}$ & $\mathrm{H}, \mathrm{V}, \mathrm{O}$ & \\
\hline 15 Cliona rhodensis & 1 & 1 & 0 & 0 & 0 & 0 & 0 & 0 & 0 & 0 & 0 & 0 & 2 & & & $\mathrm{H}$ & \\
\hline 16 Cliona vastifica & 2 & 2 & 2 & 2 & 2 & 0 & 0 & 0 & 0 & 0 & 2 & 2 & 7 & $\mathrm{~V}$ & $\mathrm{~V}, \mathrm{H}$ & $\mathrm{V}, \mathrm{H}, \mathrm{O}$ & \\
\hline 17 Cliona viridis & 3 & 3 & 3 & 3 & 3 & 3 & 3 & 3 & 3 & 3 & 3 & 3 & 12 & $\mathrm{H}, \mathrm{V}, \mathrm{O}$ & $\mathrm{H}, \mathrm{V}, \mathrm{O}$ & $\mathrm{H}, \mathrm{V}, \mathrm{O}$ & $\mathrm{H}, \mathrm{V}, \mathrm{O}$ \\
\hline 18 Crambe crambe & 3 & 3 & 3 & 3 & 3 & 1 & 1 & 1 & 1 & 2 & 2 & 3 & 12 & V.E,O & $V, E, O$ & $V, E, O$ & $\mathrm{~V}, \mathrm{H}, \mathrm{O}$ \\
\hline 19 Crella elegans & 1 & 1 & 3 & 3 & 2 & 3 & 2 & 3 & 2 & 1 & 2 & 1 & 12 & & $\mathrm{~V}, \mathrm{H}$ & $\mathrm{V}, \mathrm{H}$ & $\mathrm{H}$ \\
\hline 20 Darwinella corneostellata & 0 & 0 & 0 & 0 & 0 & 0 & 0 & 0 & 0 & 0 & 1 & 0 & 1 & $\mathrm{~V}, \mathrm{O}$ & & & \\
\hline 21 Dendroxea lenis & 0 & 0 & 0 & 0 & 0 & 0 & 0 & 0 & 0 & 0 & 2 & 0 & 1 & & $\mathrm{U}$ & $\mathrm{O}, \mathrm{H}, \mathrm{U}$ & \\
\hline 22 Dictyonella incisa & 2 & 0 & 0 & 0 & 0 & 0 & 0 & 0 & 0 & 0 & 0 & 0 & 1 & & & $\mathrm{O}$ & \\
\hline 23 Dysidea avara & 1 & 0 & 0 & 2 & 2 & 0 & 1 & 1 & 0 & 0 & 0 & 3 & 6 & & $V, E$ & $\mathrm{H}, \mathrm{V}, \mathrm{O}$ & $\mathrm{H}, \mathrm{V}, \mathrm{O}$ \\
\hline 24 Dysidea fragilis & 2 & 1 & 1 & 1 & 2 & 0 & 1 & 2 & 1 & 2 & 0 & 2 & 10 & $H_{1} I, E$ & $\mathrm{H}, \mathrm{E}, \mathrm{C}$ & $\mathrm{H}, \mathrm{V}, \mathrm{E}$ & $\mathrm{H}, \mathrm{V}, \mathrm{E}$ \\
\hline 25 Dysidea tupha & 0 & 0 & 0 & 0 & 0 & 0 & 0 & 1 & 1 & 0 & 0 & 0 & 2 & & & $\mathrm{H}$ & $\mathrm{H}$ \\
\hline 26 Erylus discophorus & 0 & 0 & 0 & 1 & 0 & 0 & 0 & 0 & 0 & 0 & 0 & 0 & 1 & U & & & \\
\hline 27 Esperiopsis fucorum & 0 & 0 & 0 & 1 & 0 & 0 & 0 & 0 & 0 & 0 & 0 & 0 & 1 & & $\mathrm{O}$ & & \\
\hline 28 Gellius angulatus & 0 & 0 & 1 & 0 & 0 & 0 & 0 & 0 & 0 & 0 & 0 & 0 & 1 & & $\mathrm{U}$ & & \\
\hline 29 Halichondria bowerbanki & 1 & 1 & 0 & 0 & 0 & 0 & 0 & 0 & 0 & 0 & 0 & 0 & 2 & & $\mathrm{H}$ & $\mathrm{H}$ & \\
\hline 30 Haliclona cinerea & 0 & 0 & 0 & 2 & 1 & 0 & 2 & 2 & 0 & 0 & 0 & 0 & 4 & $\mathrm{U}$ & $\mathrm{CC}, \mathrm{C}, \mathrm{V}$ & $O, V$ & \\
\hline 31 Haliclona fulva & 1 & 0 & 0 & 0 & 0 & 0 & 0 & 0 & 0 & 0 & 0 & 0 & 1 & & $\mathrm{C}$ & & \\
\hline 32 Haliclona indistincta & 0 & 0 & 0 & 1 & 0 & 0 & 0 & 0 & 0 & 0 & 0 & 0 & 1 & & $\mathrm{U}$ & $\mathrm{U}$ & \\
\hline 33 Haliclona mediterranea & 0 & 0 & 0 & 0 & 0 & 0 & 1 & 0 & 1 & 0 & 0 & 2 & 3 & & $\mathrm{O}$ & $\mathrm{O}$ & \\
\hline 34 Haliclona mucosa & 0 & 0 & 0 & 0 & 0 & 0 & 0 & 0 & $\hat{0}$ & 0 & 0 & 2 & 1 & & & & $\mathrm{C}, \mathrm{O}$ \\
\hline 35 Haliclona neens & 0 & 0 & 0 & 0 & 0 & 0 & 1 & 0 & 0 & 0 & 0 & 0 & 1 & $O, E$ & & & \\
\hline 36 Haliclona palmonensis & 0 & 0 & 0 & 0 & 0 & 0 & 0 & 0 & 0 & 0 & 1 & 0 & 1 & & $\mathrm{U}$ & & \\
\hline 37 Hemimycale columella & 0 & 0 & 0 & 2 & 0 & 0 & 0 & 0 & 0 & 0 & 0 & 0 & 1 & & & $\mathrm{~V}, \mathrm{H}$ & \\
\hline 38 Hymedesmia pansa & 1 & 1 & 1 & 0 & 0 & 0 & 0 & 0 & 0 & 0 & 1 & 1 & 5 & U & $U$ & V & \\
\hline 39 Hymedesmia peachi & 0 & 0 & 0 & 0 & 0 & 0 & 0 & 0 & 0 & 1 & 0 & 0 & 1 & E & & & \\
\hline 40 Hymedesmia senegalensis & 0 & 0 & 0 & 0 & 0 & 0 & 2 & 1 & 0 & 1 & 0 & 0 & 3 & $E$ & $E$ & $E$ & \\
\hline 41 Hymedesmia versicolor & 0 & 0 & 0 & 0 & 1 & 1 & 0 & 0 & 1 & 0 & 0 & 0 & 3 & & $\mathrm{O}$ & $\mathrm{O}$ & \\
\hline 42 Hymeniacidon sanguinea & 2 & 0 & 0 & 1 & 0 & 0 & 0 & 0 & 0 & 2 & 0 & 0 & 3 & $H, V, U$ & $\mathrm{H}$ & & \\
\hline 43 Ircinia faciculata & 1 & 1 & 1 & 3 & 2 & 2 & 0 & 1 & 1 & 0 & 0 & 0 & 8 & $\mathrm{H}, \mathrm{V}$ & $\mathrm{H}, \mathrm{V}$ & & \\
\hline 44 Ircinia oros & 2 & 0 & 0 & 0 & 0 & 0 & 0 & 0 & 0 & 0 & 0 & 0 & 1 & & $\mathrm{C}, \mathrm{CC}$ & & \\
\hline 45 Ircinia variablis & 1 & 1 & 0 & 0 & 0 & 0 & 0 & 0 & 1 & 0 & 0 & 2 & 4 & $\mathrm{C}$ & $\mathrm{O}$ & & \\
\hline 46 Leptolabis brunnea & 0 & $\dot{0}$ & 0 & 0 & 0 & 0 & 0 & 0 & 1 & 0 & 0 & 0 & 1 & & V & & \\
\hline 47 Microciona strepxitosa & 0 & 0 & 0 & 0 & 0 & 0 & 0 & 1 & 0 & 2 & 0 & 1 & 3 & $E$ & & $E$ & \\
\hline 48 Mycale macilenta & 0 & 0 & 0 & 0 & 1 & 0 & 0 & 0 & 1 & 0 & 0 & 0 & 2 & $\mathrm{U}$ & & $\mathrm{U}$ & \\
\hline 49 Mycale massa & 0 & 0 & 0 & 0 & 0 & 0 & 0 & 1 & 0 & 0 & 3 & 0 & 2 & & $\mathrm{U}$ & $\mathrm{U}, \mathrm{CC}$ & \\
\hline 50 Mycale micracanthoxea & 0 & 0 & 0 & 0 & 0 & 0 & 2 & 3 & 0 & 0 & 0 & 0 & 2 & & V & $V, E$ & \\
\hline 51 Mycale rotalis & 0 & 0 & 0 & 0 & 0 & 0 & 0 & 0 & 1 & 1 & 1 & 0 & 3 & & & $\mathrm{H}$ & \\
\hline 52 Myxilla iotrochotina & 0 & 0 & 0 & 1 & 0 & 0 & 0 & 0 & $\hat{0}$ & 0 & 0 & 0 & 1 & & & & \\
\hline 53 Myxilla rosacea & 2 & 0 & 0 & 0 & 0 & 0 & 0 & 1 & 0 & 0 & 0 & 0 & 2 & & $\mathrm{H}$ & V & \\
\hline 54 Oscarella lobularis & 1 & 1 & 1 & 1 & 1 & 2 & 1 & 2 & 1 & 3 & 1 & 1 & 12 & V & $\mathrm{V}, \mathrm{O}$ & & \\
\hline 55 Pellina semitubulosa & 0 & 0 & 0 & 0 & 1 & 0 & 0 & 0 & 0 & 0 & 2 & 0 & 2 & & $\mathrm{U}$ & & \\
\hline 56 Petrosia ficiformis & 1 & 0 & 0 & 0 & 0 & 0 & 0 & 0 & 0 & 0 & 0 & 0 & 1. & & 0 & & \\
\hline
\end{tabular}


Table 1 (continued)

\begin{tabular}{|c|c|c|c|c|c|c|c|c|c|c|c|c|c|c|c|c|c|}
\hline \multirow[t]{2}{*}{ Taxa } & \multirow[b]{2}{*}{$A$} & \multicolumn{10}{|c|}{ Relative abundance at Stn: } & \multirow{2}{*}{\multicolumn{2}{|c|}{ No. }} & \multicolumn{4}{|c|}{$\begin{array}{l}\text { Bathymetric distribution and } \\
\text { substrate orientation }\end{array}$} \\
\hline & & $B$ & $\mathrm{C}$ & $\mathrm{D}$ & $E$ & $F$ & I & $\mathrm{L}$ & $\mathrm{N}$ & 0 & $Q$ & & & $0-5 \mathrm{~m}$ & $5-10 \mathrm{~m}$ & $10-20 \mathrm{~m}$ & $20-30 \mathrm{~m}$ \\
\hline 57 Phorbas fictitus & 2 & 2 & 2 & 2 & 2 & 1 & 2 & 2 & 1 & 3 & 2 & 1 & 12 & $\mathrm{H}, \mathrm{V}, \mathrm{O}$ & H, V,E & $\mathrm{H}, \mathrm{V}, \mathrm{O}$ & $\mathrm{H}, \mathrm{V}$ \\
\hline 58 Phorbas paupertas & 0 & 0 & 0 & 1 & 0 & 0 & 0 & 0 & 0 & 0 & 0 & 0 & 1 & $\mathrm{U}$ & & & \\
\hline 59 Phorbas tenacior & 1 & 1 & 0 & 0 & 0 & 0 & 0 & 0 & 0 & 0 & 1 & 2 & 4 & & $\mathrm{O}$ & & \\
\hline 60 Plakina monolopha & 0 & 0 & 1 & 0 & 0 & 0 & 0 & 0 & 0 & 0 & 0 & 0 & 1 & $\mathrm{U}$ & $\mathrm{U}$ & & \\
\hline 61 Pleraplysilla spinifera & 1 & 1 & 1 & 1 & 2 & 1 & 1 & 2 & 0 & 0 & 0 & 2 & 9 & $\mathrm{C}, \mathrm{V}, \mathrm{O}$ & $\mathrm{H}, \mathrm{O}$ & $\mathrm{O}, \mathrm{C}$ & \\
\hline 62 Polymastia mamillaris & 0 & 0 & 1 & 0 & 0 & 0 & 0 & 0 & 0 & 0 & 0 & 0 & 1 & & $\mathrm{U}, \mathrm{H}$ & & \\
\hline 63 Pronax dives & 0 & 0 & 0 & 0 & 0 & 0 & 0 & 0 & 0 & 0 & 0 & 1 & 1 & & & & $\mathrm{CC}$ \\
\hline 64 Pronax lieberkühni & 0 & 0 & 0 & 0 & 0 & 1 & 0 & 0 & 0 & 0 & 0 & 0 & 1 & & & $\mathrm{H}$ & \\
\hline 65 Pronax plumosum & 0 & 0 & 0 & 0 & 1 & 0 & 0 & 0 & 0 & 2 & 0 & 0 & 2 & $\mathrm{H}, \mathrm{E}$ & $\mathrm{H}, \mathrm{E}$ & & \\
\hline 66 Phyteras fusifera & 1 & 0 & 0 & 1 & 0 & 0 & 0 & 0 & 0 & 0 & 0 & 0 & 2 & & 0 & & \\
\hline 67 Raspaciona aculeata & 1 & 0 & 0 & 0 & 0 & 0 & 0 & 0 & 0 & 0 & 0 & 1 & 2 & & $\mathrm{O}$ & $\mathrm{O}$ & \\
\hline 68 Sarcotragus muscarum & 1 & 1 & 1. & 3 & 2 & 0 & 0 & 0 & 0 & 0 & 1 & 0 & 6 & $\mathrm{O}$ & $\mathrm{O}, \mathrm{V}$ & $0, \mathrm{~V}$ & $\mathrm{H}$ \\
\hline 69 Sarcotragus spinosula & 0 & 1 & 0 & 1 & 0 & 0 & 0 & 0 & 0 & 0 & 0 & 1 & 3 & & 0 & 0 & \\
\hline 70 Scopalina lophiropoda & 1 & 2 & 2 & 1 & 3 & 1 & 0 & 0 & 0 & 0 & 1 & 2 & 8 & & V & $\mathrm{V}, \mathrm{O}$ & $\mathrm{H}, \mathrm{CC}$ \\
\hline 71 Scopalina madeirensis & 0 & 1 & 0 & 0 & 0 & 0 & 0 & 0 & 0 & 0 & 0 & 0 & 1 & & & $\mathrm{H}$ & \\
\hline 72 Spongia agaricana & 1 & 2 & 0 & 1 & 2 & 0 & 0 & 0 & 0 & 0 & 1 & 2 & 6 & & 0 & $\mathrm{O}$ & $\mathrm{H}$ \\
\hline 73 Spongia officinalis & 1 & 1 & 0 & 1 & 1 & 0 & 0 & 0 & 0 & 0 & 0 & 1 & 5 & V & $\mathrm{O}, \mathrm{H}, \mathrm{V}$ & $E$ & \\
\hline 74 Spongia vilgurtosa & 1 & 1 & 0 & 0 & 0 & 0 & 0 & 0 & 0 & 0 & 0 & 1 & 3 & & $\mathrm{E}$ & & \\
\hline 75 Stylopus dujardini & 0 & 0 & 0 & 2 & 3 & 1 & 3 & 2 & 2 & 1 & 1 & 0 & 8 & $\mathrm{H}, \mathrm{V}, \mathrm{U}$ & $\mathrm{H}, \mathrm{V}, \mathrm{U}$ & $E, V, O$ & $\mathrm{H}, \mathrm{V}$ \\
\hline 76 Suberitis domuncula & 1 & 1 & 2 & 0 & 0 & 1 & 1 & 1 & 1 & $i$ & 1 & 1 & 10 & $E$ & $\mathrm{E}$ & $\mathrm{E}, \mathrm{O}$ & \\
\hline 77 Tedania anhelans & 0 & 0 & 0 & 1 & 0 & 0 & 0 & 0 & 0 & 0 & 1 & 0 & 2 & & $\mathrm{CC}, \mathrm{H}$ & & \\
\hline 78 Terpios fugax & 0 & 1 & 1 & 0 & 1 & 1 & 1 & 1 & 1 & 1 & 0 & 1 & 9 & U & $V, E$ & $\mathrm{~V}, \mathrm{H}$ & \\
\hline 79 Tethya aurantium & 1 & 1 & 0 & 0 & 1 & 1 & 0 & 0 & 0 & 0 & 0 & $i$ & 5 & $\mathrm{C}, \mathrm{CC}$ & $O^{12}$ & $\mathrm{O}$ & \\
\hline 80 Timea unistellata & 1 & 1 & 1 & 1 & 0 & 0 & 0 & 0 & 0 & 0 & 0 & 1 & 5 & & $\mathrm{U}$ & 0 & $\mathrm{O}$ \\
\hline 81 Ulosa stuposa & 0 & 0 & 0 & 1 & 0 & 0 & 0 & 0 & 0 & 0 & 0 & 0 & 1 & & $\mathrm{E}$ & & \\
\hline Total species & 37 & 31 & 21 & 36 & 24 & 18 & 16 & & 18 & 19 & 30 & 3 & & & & & \\
\hline
\end{tabular}

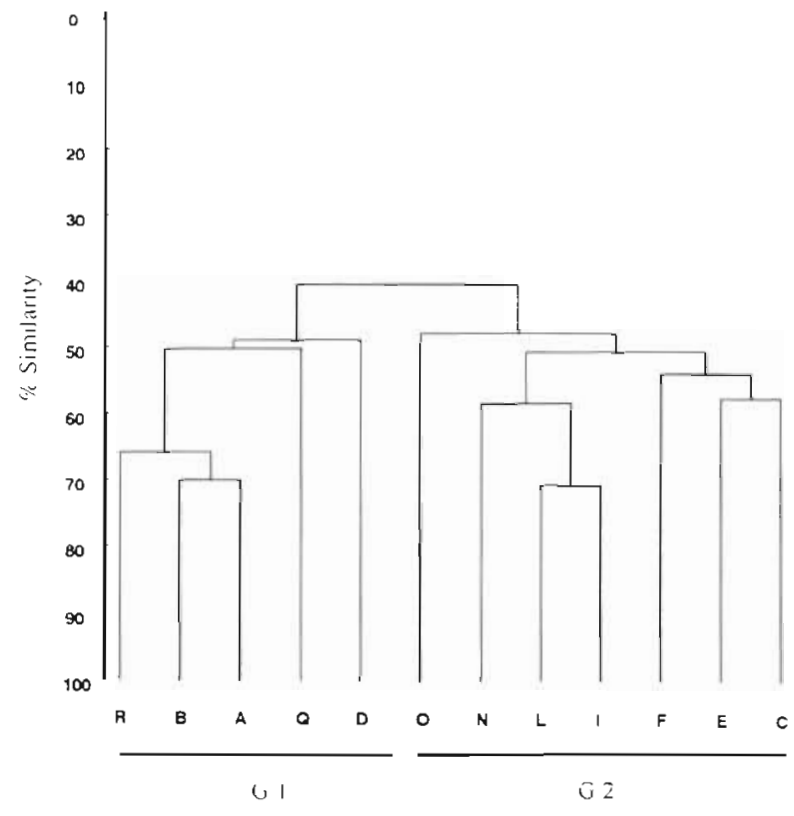

Fig. 3. Dendrogram showing classification of 12 sampling stations using the Bray-Curtis index crambe, Crella elegans, Oscarella lobularis), or as species typical of harbour areas (Mycale micracanthoxea, Hymedesmia senegalensis). Ten species were responsible for approximately $50 \%$ of the dissimilarity between group G1 and group G2 (Table 2).

Table 2. Breakdown of average dissimilarity between groups G1 and G2 into contributions from each species; species are ordered in decreasing contribution (only partly given). $\bar{\delta}_{\text {, }}$ contribution of the $i$ th species to the average Bray-Curtis dissimilarity between the groups; $\Sigma \bar{\delta}, \%$ : cumulative percentage Average dissimilarity between groups $=42.16(\mathrm{SD}=9.076)$

\begin{tabular}{|c|c|c|}
\hline Species & $\bar{\delta}_{1}$ & $\Sigma \bar{\delta}_{i} \%$ \\
\hline Spongia agarıcina ${ }^{d}$ & 5.03 & 5.03 \\
\hline Chondrosia reniformis & 5.02 & 10.05 \\
\hline Antho involvens & 4.9 & 14.94 \\
\hline Phorbas tenacior ${ }^{\circ}$ & 4.42 & 19.36 \\
\hline Cliona vastifica ${ }^{a}$ & 4.36 & 23.72 \\
\hline Aplysilla rosea & 4.20 & 27.92 \\
\hline Sarcotragus muscarum & 3.68 & 31.68 \\
\hline Stylopus dujardini & 3.68 & 35.36 \\
\hline Scopalina lophiropoda ${ }^{d}$ & 3.59 & 38.95 \\
\hline Dysidea avara & 3.24 & 42.19 \\
\hline
\end{tabular}




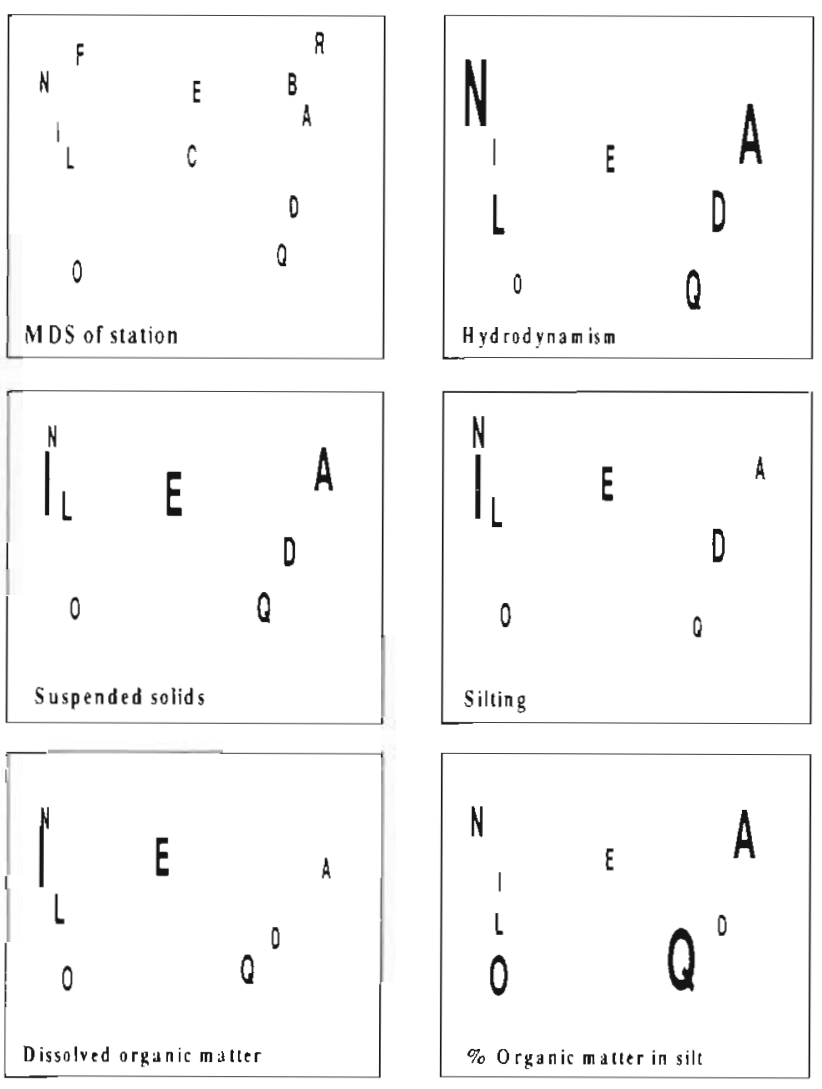

Fig. 4. Two-dimensional non-metric multi-dimensional scaling (MDS) plot of stations based on a similarity matrix species established by Bray-Curtis index with each abiotic variable superimposed as letters of size varying in proportion to the abiotic value (stress $=0.124$ )

The results of the MDS generally confirm the results of the cluster analysis (Fig. 4) and permit us to distinguish between the group of stations at the extremes of the bay ( $A$ and $B$ on the west, and $R$ on the east) to which the stations at the west (D) and east (Q) margins are closely situated, and the group of stations corresponding to the internal areas (I, L and $\mathrm{N}$ )

\section{Environmental variables}

A set of 5 environmental variables was recorded for 8 sites: suspended solids, dissolved organic matter, hydrodynamism, silting, and \% organic matter (SOM) in the silt.

Fig. 5 shows a multiple 'box-and-whisker' plot for each abiotic variable analysed. The magnitude of the various parameters generally shows an inverse relationship between the group of stations located at the inner parts of the bay and the group of stations at the extremes. The highest average annual values for suspended solids were registered at Stn I (17.35 $\left.\mathrm{mg} \mathrm{I}^{-1}\right)$, which also had the maximum annual values $152.35 \mathrm{mg}$ $\left.1^{-1}\right)$. Silting tended to be higher at inner areas, where, as in the previous case, the maximum annual values $\left(29.78 \mathrm{~g} \mathrm{~m}^{-2} \mathrm{mo}^{-1}\right)$ and the highest average annual values $\left(15.83 \mathrm{~g} \mathrm{~m}^{-2} \mathrm{mo}^{-1}\right)$ were registered at Stn I. Hydrodynamism seems to act inversely to silting; the lowest values were registered at Stn I ( $4.39 \mathrm{~V})$, and at a small partly enclosed port area $(\mathrm{O})(2.85 \mathrm{~V})$. The maximum annual values $(17.6 \mathrm{~V})$ were registered at $\mathrm{Stn} \mathrm{N}$, and the highest average annual values (7.62) occurred at Stn A. The annual average of dissolved organic matter was very similar at the various stations, with the highest average values registering at $\operatorname{Stns} E\left(3.77 \mathrm{mg} \mathrm{l}^{-1}\right), \mathrm{L}$ ( $\left.3.53 \mathrm{mg} \mathrm{l}^{-1}\right)$ and $1\left(4.16 \mathrm{mg} \mathrm{I}^{-1}\right)$, in the interior of the bay, and at $Q(3.47 \mathrm{mg} 1-1)$, more externally situated; the lowest average values were registered at Stns A (3.13 $\left.\mathrm{mg} \mathrm{l}^{-1}\right)$ and $\mathrm{D}\left(3.15 \mathrm{mg} \mathrm{l}^{-1}\right)$.

In order to establish significant correlations between variables, we carried out a regression analysis and obtained the results shown in Table 3 .

The correlations established between the different parameters mainly present a linear-type regression. In the majority of the cases a fairly logical relationship was established in accordance with the function of the different variables. A clear positive linear relationship was found between suspended solids and silting, which indicates that an increase in suspended solids translates into an increase in silting. On the other hand, silting and SOM follow a negative multiplica-

Table 3. Summary of the abiotic variables which showed significant correlation ( $\mathrm{r}$ )

\begin{tabular}{|c|c|c|c|c|}
\hline & Model & $\mathrm{r}$ & $\mathrm{R}^{2}$ & $\mathrm{p}$ \\
\hline Solids vs dissolved organic matter & Linear & 0.747 & 51.82 & 0.032 \\
\hline Solids vs silting & Linear & 0.719 & 51.82 & 0.044 \\
\hline Solids vs g organic matter in silt & Linear & 0.805 & 64.82 & 0.015 \\
\hline Silting vs dissolved organic matter & Linear & 0.747 & 55.91 & 0.032 \\
\hline Silting vs SOM & Multiplicative $Y=a X^{b}$ & -0.888 & 78.89 & 0.032 \\
\hline SOM vs $g$ organic matter in silt & Multiplicative $Y=a X^{b}$ & -0.843 & 71.21 & 0.008 \\
\hline Hydrodynamism vs beta diversity & Linear & 0.666 & 45.45 & 0.049 \\
\hline
\end{tabular}


tive-type model, which seems to indicate that small variations in silting, around 1 to $5 \mathrm{~g} \mathrm{~m}^{-2} \mathrm{mo}^{-1}$, translate into elevated SOM values, and starting from certain silting values (>6 $\mathrm{g} \mathrm{m}^{-2} \mathrm{mo}^{-1}$ ), SOM is maintained at fairly stable levels. As is shown in Fig. 6, SOM tended to be greater at the stations located at the extremes of the bay than at the central areas. However, the real quantity of organic matter which settles $(\mathrm{g})$ is much greater in the central areas of the bay, due to the fact that silting tends to be greater in these areas (Fig. 5B). The relationship of SOM versus $g$ organic matter follows a negative multiplicative regression model which clearly indicates that when SOM is low, the real quantity of organic matter (g) which settles is high (internal stations), and that when the SOM is high, the real quantity of organic matter which settles ( $g$ ) is less (external stations) (Fig. 7). This relationship seems fairly logical, given that not only are the internal parts of the bay withstanding wastes from a large industrial area, but there is also a continuous flow of urban and fluvial discharges which increase silting (composed of organic and inorganic matter), while at the extremes of the bay silting seems less and is mainly composed of organic matter from the same environment (Fig. 5B, D).

Hydrodynamism is inversely related to silting but the relationship is non-significant (Fig. 6). Nevertheless, Fig. 6 suggests that with more data there may have been a relation, with the lowest values for silting being registered when hydrodynamism is highest and vice versa. The only abiotic variable (average annual values) which shows a significant correlation to beta diversity is hydrodynamism: a linear regression model exists between the 2 variables with a correlation coefficient ( $r$ ) equal to 0.67 (Table 3 ).

Stn $N$, which had an elevated hydrodynamism $(6.4 \mathrm{~V})$, had lower beta diversity values than expected in relation to the rest of the stations. If we exclude the value of this station in the regression with beta diversity, we obtain a very significant new model $(r=0.83$; $\mathrm{p}=0.05)$.

\section{BIO-ENV procedure: Spearman rank correlation}

The BIO-ENV procedure selects which subset of abiotic variables maximises a correlation between the biotic and abiotic similarity matrices.
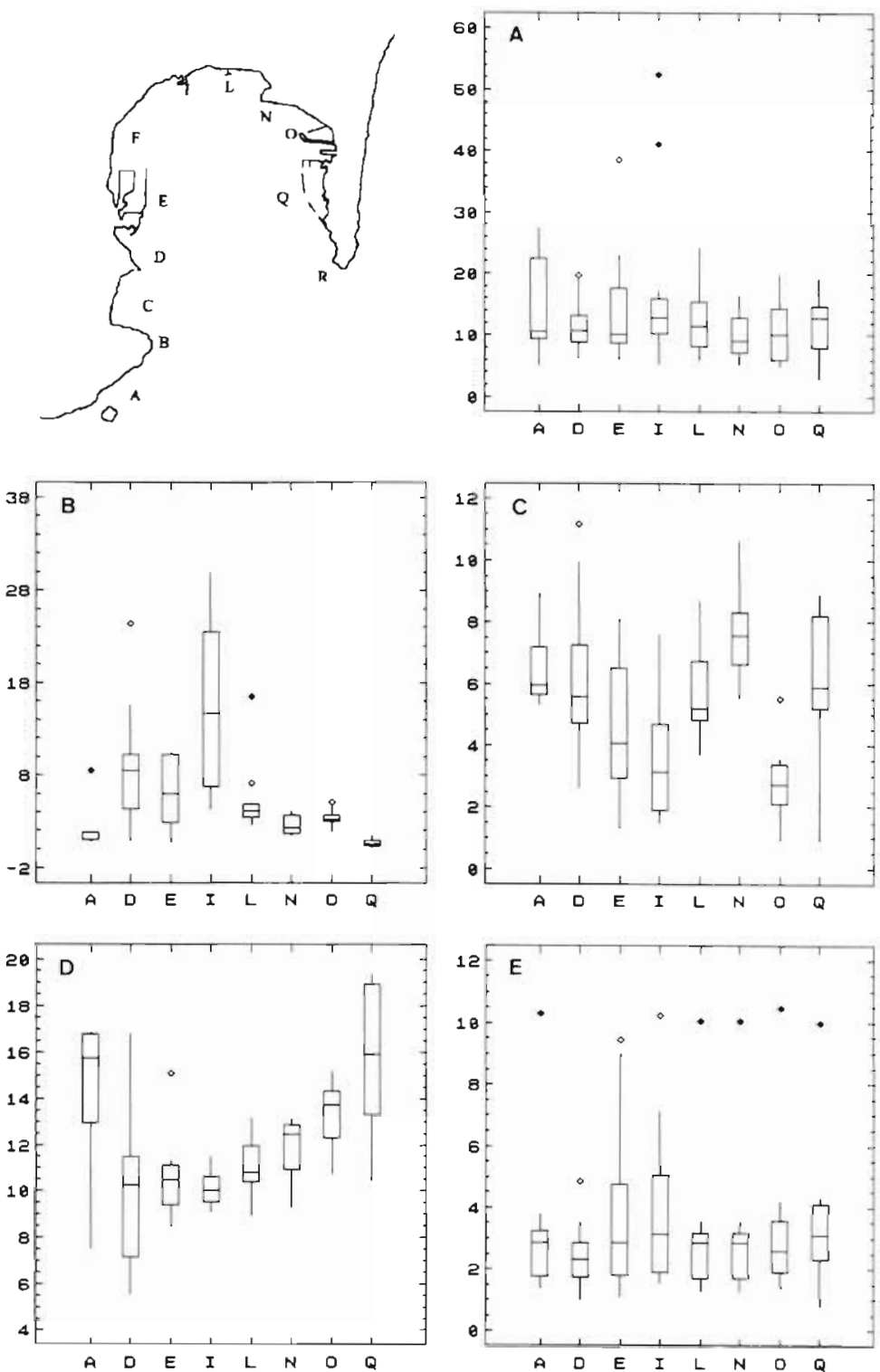

Fig. 5. Multiple 'box-and-whisker' plot for each abiotic variable at 8 sampling stations. (A) Suspended solids, $\mathrm{mg} \mathrm{l}^{-1}$; (B) silting, $\mathrm{g} \mathrm{m}^{-2} \mathrm{mo}^{-1}$; (C) hydrodynamism, $V_{i}$ (D) \% organic matter (SOM), \%; (E) dissolved organic matter, $\mathrm{mg} \mathrm{l}^{-1}$ The small black or open diamonds indicate outliers

Table 4 shows the combinations of variables which give rise to the largest rank correlation $\left(\rho_{\mathrm{s}}\right)$ between biotic and abiotic sample similarities. The variable which best groups the sites, in a manner consistent with the faunal pattern, is hydrodynamism $\left(\rho_{\mathrm{s}}=0.48\right)$; next best is SOM $\left(\rho_{s}=0.47\right)$. The best 2 -variable combinations are hydrodynamism and $\operatorname{SOM}\left(\rho_{\mathrm{s}}=0.6\right)$, and hydrodynamism and silting $\left(\rho_{s}=0.53\right)$. The best 3 -variable combination is hydrodynamism-silting-SOM $\left(\rho_{\mathrm{s}}=\right.$ 0.57 ). The relationship that hydrodynamism shows with SOM can be explained because the areas where a greater diversity was found are areas with good water renewal and generally less organic matter (total g). 


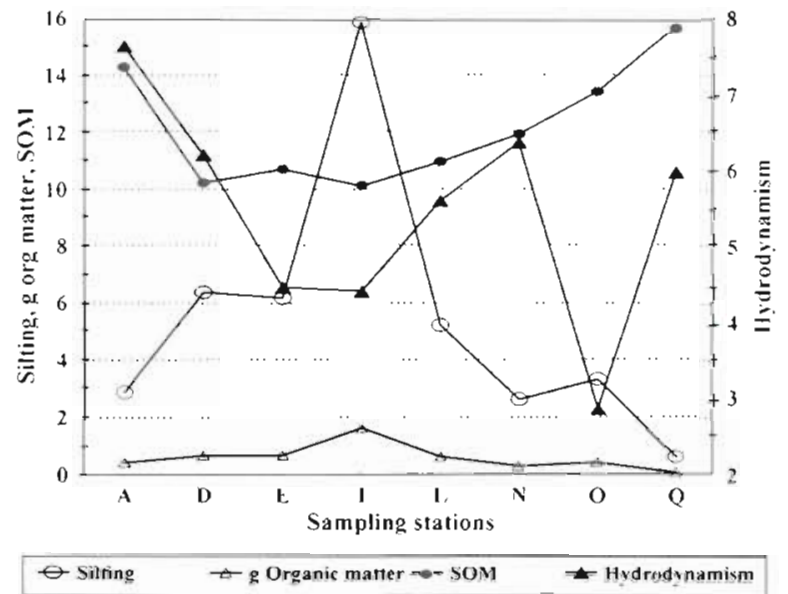

Fig. 6. Average value of 4 abiotic variables in the 8 sampling stations

\section{Factorial analysis}

With the data from Table 1, we carried out a factorial analysis in order to try to simplify the relationships formed between different species in terms of their distribution and relative abundance in Algeciras Bay (Fig. 8).

Factor I clearly discriminates between 2 groups of species: a group formed by species which generally have a very precise distribution (Acanthella acuta, Tedania anhelans, Cliona rhodensis, Reniera fulva, Reniera mucosa, Petrosia ficiformis, Haliclona neens, Dictyonella incisa) (negative side of axis), and a group we can categorise as composed of eurytopic species widely present in the different habitats and enclaves

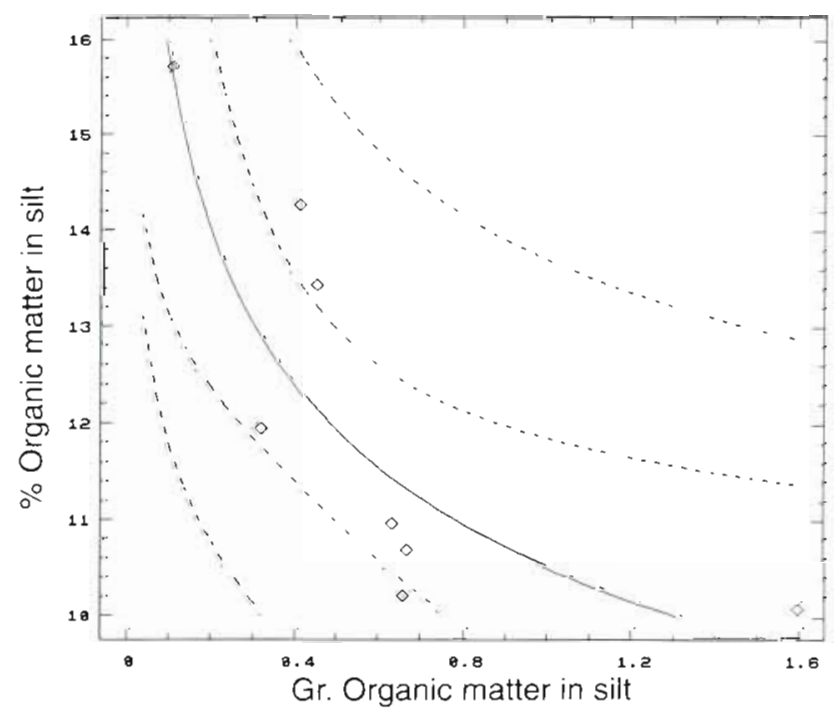

Fig. 7. Multiplicative regression between \% organic matter in silt (SOM) and $g$ organic matter (the dotted lines are the confidence limits at $95 \%$ )
Table 4. Combinations of variables, taken $K$ at a time, giving the largest rank correlations $\left(p_{\mathrm{s}}\right)$ between biotic and environmental similarity, measured by standard Spearman coefficient. Bold type indicates the combination with the greatest $\rho$ overall. All variables are log-transformed

\begin{tabular}{ccc}
\hline$K$ & \multicolumn{2}{c|}{ Best vanable combinations $\left(\rho_{\mathrm{s}}\right)$} \\
\hline 1 & Hydrodynamism & Silting Organic Matter \\
& $(0.486)$ & $(0.471)$ \\
2 & Hydrodynamism - SOM & Hydrodynamism - Silting \\
3 & $(0.600)$ & $(0.537)$ \\
& Hydrodynamism - & Hydrodynamism - Dissolved \\
& Silting - SOM (0.575) & Organic Matter - SOM (0.507) \\
4 & Silting - Hydrodynamism - \\
& Dissolved Organic Matter - SOM (0.500)
\end{tabular}

studied, such as Stylopus dujardini, Crella elegans, Phorbas fictitius, Cliona celata, C. viridis, Dysidea fragilis, Suberites domuncula, Terpios fugax, Hymeniacidon sanguined, Scopalina lophiropoda, Cliona vastifica. Pleraplysilla spinifera, Dysidea avara (positive side of axis).

On the other hand, Factor II seems to correspond to the tolerance level of the species. The positive side of the axis shows a group of species which are distributed throughout the areas of the bay taken into account: Stylopus dujardini, Crella elegans, Crambe crambe, Phorbas fictitius, Cliona viridis, C. celata, Oscarella lobularis, Dysidea fragilis, Suberites domuncula, Terpios fugax, or throughout zones subject to non-optimal environmental conditions: Mycale micracanthoxea, Haliclona cinerea, Hymeniacidon sanguinea. The negative side of the axis shows a group of species which are distributed throughout practically all of the bay, except for the most internal areas (piers, shipyards), and which can be considered to have a medium level of tolerance between the most eurytopic and the strictly stenotopic species: C. vastifica, Cacospongia scalaris, Aplysilla rosea.

\section{DISCUSSION AND CONCLUSIONS}

\section{Description of the sponge communities and characterization of species groups}

The various harbour works and civil constructions along the bay's littoral, along with different types of urban and industrial wastes, condition the heterogeneity of the environment under research. Factors which regulate specific richness are directly related to the heterogeneity of the environment. In Algeciras Bay we showed that this heterogeneity has conditioned the number of species present, and we generally obtained 
a clear differentiation between areas subject to environmental stress (internal) and areas with more normal conditions (external). We obtained the same differentiation by means of classification and ordination analyses. In this way, specific richness and beta diversity provide a quick and efficient method of obtaining information about the sponge community.

Therefore, in the description of the communities we observed 2 major groups: the first one is composed of the stations located at the margins and external parts of the bay, and the second one is composed of the stations located in the inner areas of the bay.

The external areas include species like Reniera mucosa, $R$. fulva, Ircinia oros, Petrosia ficiformis, Phorbas tenacior, Cliona rhodensis, Dendroxea lenis (negative side of Factor I of the factorial analysis). The first two, $R$. fulva and $R$. mucosa, are frequent species in the outer regions of the bay and seem very sensitive to light and extreme values of rate of sedimentation. They are found in protected areas like crevices, bottoms of small cavities and overhangs. In general they are absent from stations with a rate of sedimentation higher than $2.8 \mathrm{~g} \mathrm{~m}^{-2} \mathrm{mo}^{-1}$, and hydrodynamism below $7.6 \mathrm{~V}$. These species, though, are absent from Stn $O$ which has semi-dark conditions, with levels of sedimentation $\left(2.6 \mathrm{~g} \mathrm{~m}^{-2} \mathrm{mo}^{-1}\right)$ and suspended solids ( $9.8 \mathrm{mg} \mathrm{l}^{-1}$ ) similar to the ones found at the previous stations. Nevertheless, their absence seems to be explained by the levels of hydrodynamism which are the lowest of all those registered $(2.8 \mathrm{~V})$. At Stn N, which apparently has values somewhat similar to those found at other stations where higher values of diversity have been found $(A, D$, etc.), their absence can be justified in view of the elevated hydrodynamism values which sometimes reach $17.6 \mathrm{~V}$, and which in some way can hinder the larval emplacement of some species. Other species, like Spongia agaricina and Scopalina lophiropoda, show a less restricted distribution than the ones previously cited, with both these species being found from the

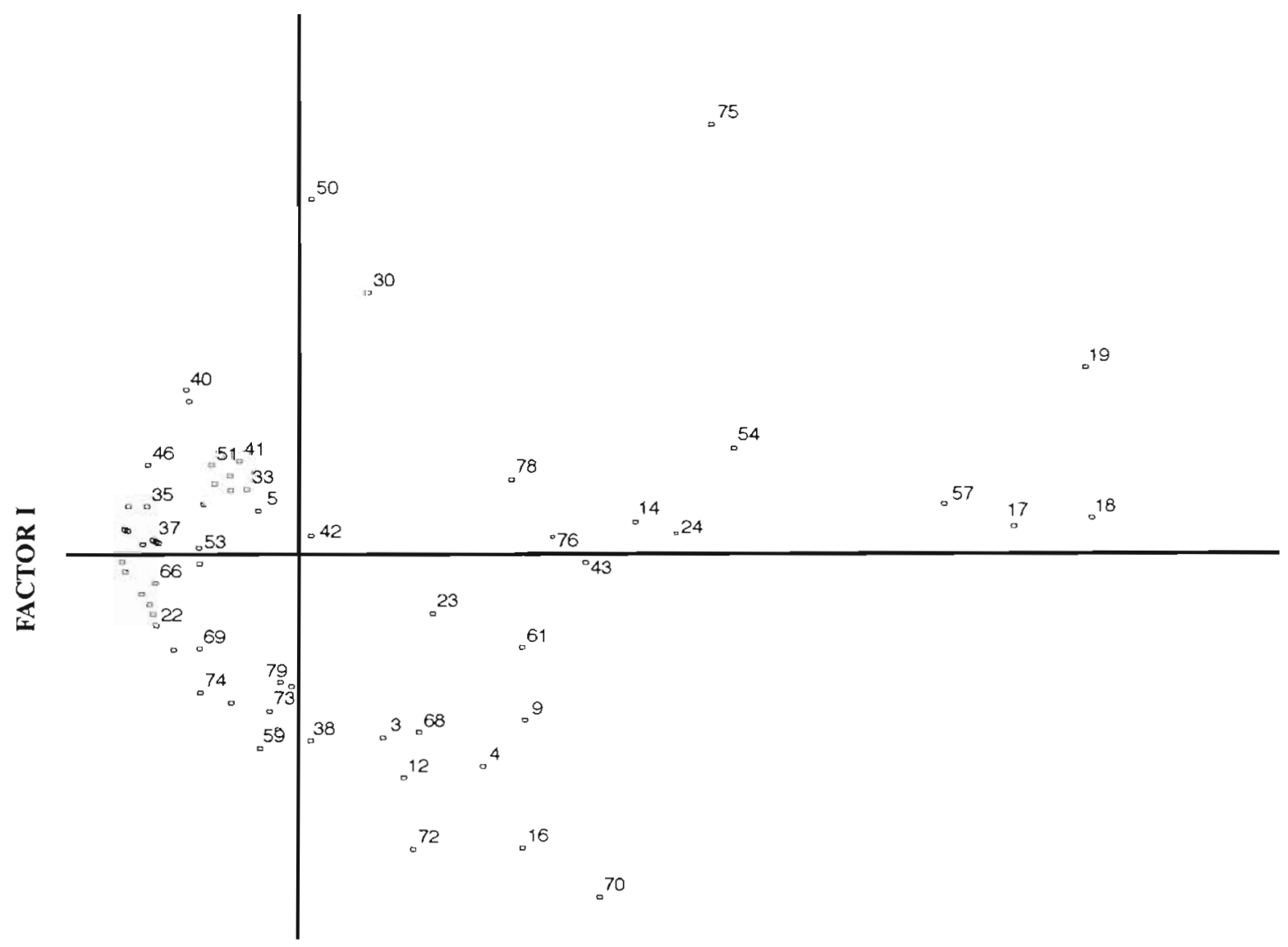

\section{FACTOR II}

Fig. 8. Factorial analysis in a 2-dimensional ordination of species on plane created by first 2 factorial axes. Data were standardized. The \% variation explained by factor $I$ is 76.4 and by Factor 11 is $15.2(\%$ variance explained $=91.6 \%)$. Numbers refer to species as in Table 1 


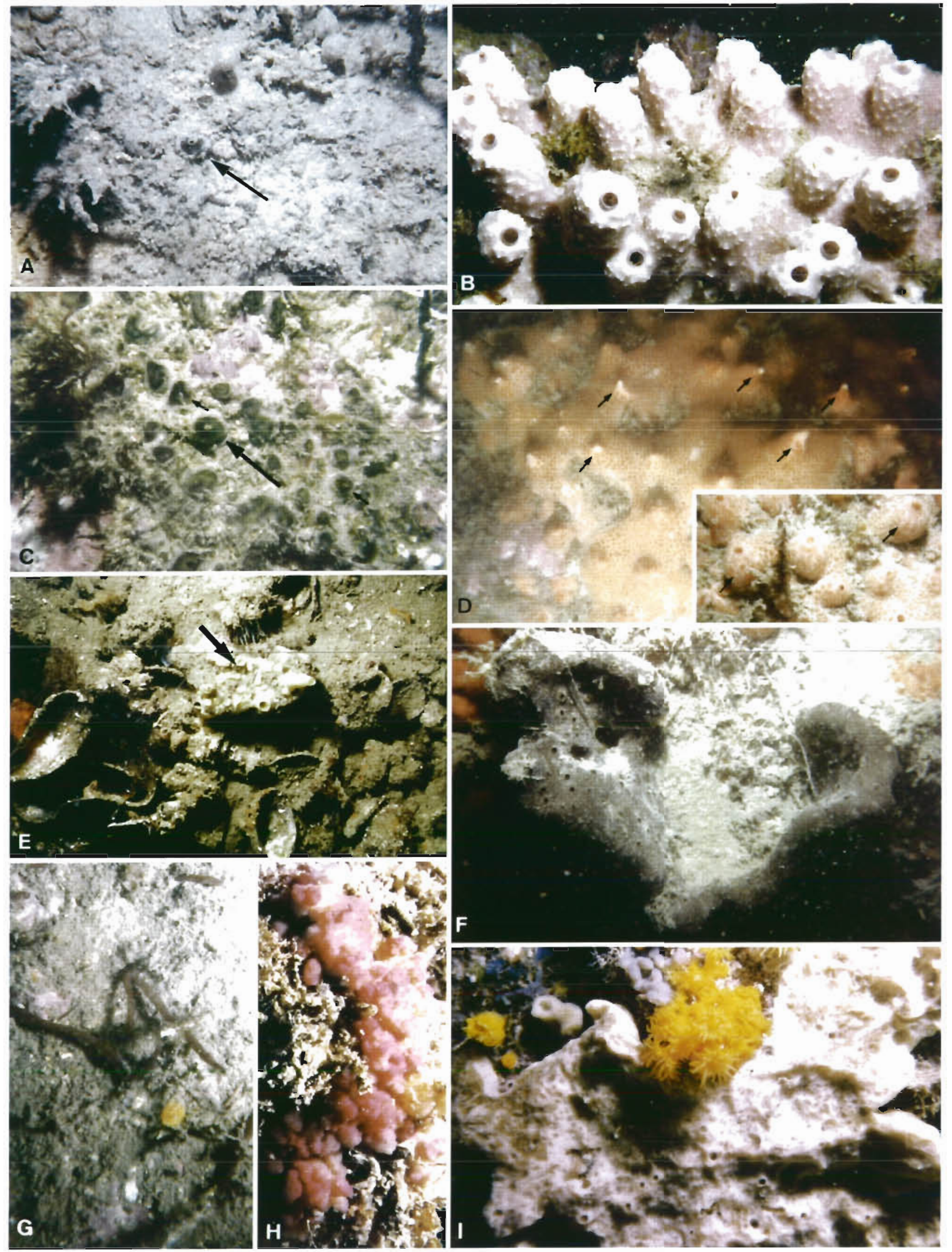


exterior locations of the bay up to Stn $E$ along the west margin, and up to $\operatorname{Stn} Q$ along the east margin. These species along with $C$. vastifica and $P$. tenacior seem to be good discriminators of groups G1 and G2 (Table 2). They were not found at the internal stations (I, L, N, and O), and the stations where they are located are subject to more extreme environmental conditions: rate of sedimentation between 0.65 and $6.35 \mathrm{~g} \mathrm{~m}^{-2} \mathrm{mo}^{-1}$, hydrodynamism between 4.4 and $7.6 \mathrm{~V}$, and $\mathrm{g}$ SOM between 0.1 and $0.6 \mathrm{~g} \mathrm{~m}^{-2} \mathrm{mo}^{-1}$.

Among the species we have considered, Cliona celata, C. viridis, Hymeniacidon sanguinea, Oscarella lobularis (Fig. 9), Dysidea fragilis, Crambe crambe, etc. (positive side of Factor II), showed a great adaptive plasticity to selection by substrate, depth and relationship to environmental variables. C. viridis is abundant in the interior areas of the bay, where it is always present on vertical or horizontal walls in port constructions. It can tolerate strong hydrodynamism situations as well as moderate currents. The beta form of $C$. viridis frequently appears when sedimentation and muddiness are high. The alpha form is almost always found on calcareous algae in areas of high hydrodynamism and good water renewal (Stns $A, B$ and D), and is rarer in the interior of the bay. This species' level of tolerance to the environmental factors we have considered is quite high. Both species were found in environments with high silting $\left(15.8 \mathrm{~g} \mathrm{~m}^{-2} \mathrm{mo}^{-1}\right)$, a total quantity of sedimented organic matter of $1.5 \mathrm{~g} \mathrm{~m}^{-2} \mathrm{mo}^{-1}$, reduced values of hydrodynamism $(2.8 \mathrm{~V})$, and suspended solids values of up to $52.3 \mathrm{mg} \mathrm{l}^{-1}$.

In port environments we frequently found the species Mycale micracanthoxea (Stns I and L) on vertical walls or covering barnacle shells, bryozoans etc.; Hymedesmia senegalensis ( $\mathrm{I}, \mathrm{L}$ and $\mathrm{O}$ ) also over barnacles; and Pronax plumosum (E and O) and Stylopus dujardini (D, E, F, I, L, N, O and Q), all enclosed within the positive axis of Factor II of the PCA, but with a much more restricted distribution than the previous species.

\section{Relation with abiotic variables}

Sponges are one of the main benthic groups. Their trophic role in benthic ecosystems is a filtering one (Vacelet 1978). They feed on particles in suspension and dissolved organic matter, and their growth is inhibited by a heavy and intermittent silting load, or by low and continuous levels of silting, since a considerable amount of energy is necessary in order to clean the obstructed canals and orifices. Silting can cause a reduction in the pumping rate, and if this reduction is excessive it can even produce a complete stop in filtration (Reiswig 1971).

Generally, it seems that the recorded silting values are not high enough to restrict the distribution of the majority of the species found. Some of these species have adapted to environments with high rates of silting, developing structures which permit them to survive in conditions with these high levels, like $D y s i-$ dea avara, Crella elegans, or Halichondria bowerbanki (Fig. 9), and some even seem to prefer silting environments where they can come to dominate over the rest of the species, as in the case of Cliona celata or $C$. viridis. It was previously found that these 2 species $(C$. celata and $C$. viridis) withstood the most elevated silting and suspended solids values of all the species from the genus Cliona found in Algeciras Bay (Carballo et al. 1994). Other species, like Phorbas tenacior, C. rhodensis, Reniera mucosa and $R$. fulva, seem much more sensitive to these factors.

There are no bibliographical data which permit a comparison with the data we have obtained. Bakus (1967), in experiments conducted at Fanning Island, Central Pacific, indicated that many sponges and ascidians are adversely affected by sediment deposition (by burial and clogging of canals and chambers). However, it is difficult to compare our results with those obtained by the method employed by Bakus, which consisted of measuring the height of the layer of sedimentation after different periods of time. This

Fig. 9. Sponges photographed in Algeiras Bay. (A) Cliona viridis, typical ' $r$ ' species buried under a fine layer of silt. The arrow indicates a semi-enclosed exhalant papilla. (B) Dysidea avara in outer area of Algeciras port (Stn E). The specimens found on horizontal substrata have developed exhalant elevations various centimeters high in response to silting (the sediment that covered part of the body was removed). (C) Same as A after gently removing sediment layer. The arrows indicate the exhalant papillae which remain closed. We have observed that $C$. viridis can remain in this state for several weeks without showing signs of mortality or size reduction. (D) Crella elegans, a eurytopic species, after removing the sediment layer which was covering it. The arrows indicate small exhalant elevations which protruded from the sediment layer and allowed hydric exchange. In a later state (inset), these small elevations become true exhalant chimneys. (E) Cliona celata, typical ' $r$ ' species, growing on biodetritic bottoms in Stn L (CEPSA pier). (F) Although the species Spongia agaricina has shown a more restricted distribution than the previous species, it also shows a certain tolerance to high sedimentation as shown in the image (G) Halichondria bowerbanki sends out long

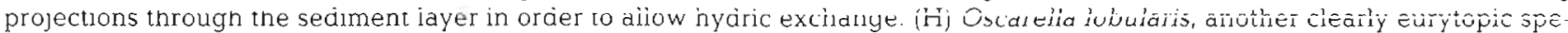
cies with a wide distribution in Algeciras Bay, demonstrates this distinctive morphotype in the sampling areas within the main interior port areas of the bay (Stn O). (I) Reniera mucosa, a species which has behaved stenotopically and with a definite ' $\mathrm{K}$ strategy in Algeciras Bay, found only in the exterior areas of the bay (Stn R) 
author found that with sediment layers between 3 and $10 \mathrm{~mm}$ thick all the sponges died except for 1 small Haliclona sp. and 2 small specimens each of Halisarca sp. and Terpiox sp. It seems that some species like Halisarca sp. can transform themselves and raise numerous tubercules that loosely attach to the slab. Bakus observed that the sponges which were unable to withstand this high rate of sedimentation either reduced their size considerably (the Dictyoceratid sponge was half its former size and contained a considerable amount of sediment), or simply died. Other species like Halisarca sp., though, showed an appreciable increase in size, and were packed with sediment, or they developed special structures which allowed them to survive in those conditions such as we observed in Dysidea avara, Halichondria bowerbanki or Crella elegans (Fig. 9)

Muricy et al. (1991) also suggest that 2 factors are particularly important at the local scale in species distribution; one which distinguishes photophilic from cryptic microhabitats, and the other which distinguishes sedimentation/abrasion rates. They found that species like Polymastia sp. Mycale arenosa, Dysidea fragilis and Petromica cyocalliptoides withstood high sedimentation and abrasion rates at depths between 4 and $8 \mathrm{~m}$.

Nevertheless, hydrodynamism is the factor which presented the most direct relationship with species distribution and beta diversity, whether in an isolated manner or in conjunction with other variables like silting, dissolved organic matter, etc. Water movement is another important factor, more so in areas. Extreme values of this factor quickly act in a restrictive manner. In this way, extreme movement can impede the fixation of larvae and can even cause destruction of adults On the other hand, excessive stagnation can cause a reduction in the water's rate of renewal (Sará \& Vacelet 1973).

In the first few sublittoral meters we can find species like Ircinia fasciculata, which is abundant in shallow photophilic bottoms without showing an affinity towards a specific enclave; or Mycale macilenta which seems to prefer waters which are calmer and less renewed, where it associates with Caulerpa prolifera rhizomes. The latter is also frequent over barnacles on vertical walls in port areas, and even under rocks. Another species which is present in illuminated bottoms regardless of the water's rate of renewal is Hymeniacidon sanguinea, which has been detected on C. prolifera bottoms with low hydrodynamism and high silting, in areas of exposed rocks at the exterior of the bay ( $\operatorname{Stn} \mathrm{A}$ ), in closed port areas, and even in enclaves under rocks in shallow depths. Muricy et al. (1991) found that the species Cliona celata can stand high levels of hydrodynamism and light intensity. The species which are more exigent in regard to these parameters are the ones previously mentioned (Phorbas tenacior, Reniera mucosa, R. fulva, C. rhodensis), which are mainly located at the exterior of Algeciras Bay. In any case, what seems clear is that the species distribution cannot be explained solely on the basis of 1 single environmental variable, but rather on a combination of factors.

\section{Sponges as bioindicator species of environmental stress}

As a final consideration, the objective of any ecological study would be to find the cause-and-effect relationship(s) between environmental parameters (including biotic influences), as well as the species and individual patterns of distribution. Organisms can exist in a determined place only if their 'ecological valency' (the group of biological conditions which permit a species or isolated animal to survive) is not in conflict with the environment of the said place (Muller 1974). For this reason, animals and plants are live indicators of environmental characteristics. The usefulness of a biological indicator, then, depends on a narrow ecological valency such as that which characterises stenotopic species, strictly related to a determined environment. Eurytopic species, for their part, can exist in very diverse conditions

The degree of stenotopy can be a good characteristic of indicator species. In fact, an ideal pollution-indicator species would be a highly stenotopic species restricted to polluted environments. In general, stenotopic species seem more likely to be pollution-sensitive species than eurytopic ones. Indicator species, if they are to be used at all in biomonitoring, must be considered only in a regional context.

Mycale micracanthoxea was described from several localities in the Dutch Delta (SW Netherlands). It was reported as very common on harbour poles and pontoons (Buizer \& Soest 1977), growing attached to shells, barnacles, tunicates and hydroids. The species is also very abundant in the study zone, where it occurs on outer vertical surfaces in the harbour or on pontoons, growing over shells, bryozoans, barnacles (Carballo \& Garcia-Gómez 1994). The particular environmental conditions where $M$. micracanthoxea is located, always close to harbour zones where it is extremely abundant, suggest that it is possible that this species is a good indicator of port environments. Another species of the same genus, Mycale microsigmata, is considered by Muricy (1989) to be a good 'control' species in this kind of environmental study due to the tolerance demonstrated in the polluted area at Arraial do Cabo (Southeastern Brazil). 
In another study, Muricy (1991) found a group of species in the areas of maximum pollution from the sewage outfall at Cortiou (Marseille, France), some of which, like Cliona celata, C. viridis, Hymeniacidon sanguinea, Mycale macilenta, Oscarella lobularis, Dysidea fragilis, show a similar behaviour in Algeciras Bay, presenting a great adaptive plasticity for selection by substrate, depth, and relationship to environmental variables as we have stated earlier. They are species also typical of biofouling (Sará 1974), and categorised as pioneer and opportunistic (' $r$ ' strategy), characterised by their weak ecological specialisation (eurytopic). Conversely, ecosystems which are not under environmental stress generally present a high specific diversity (Margalef 1968).

The majority of the species present in these types of populations are ' $K$ ' strategists, that is, more ecologically specialised, as the already cited Reniera mucosa, $R$. fulva, etc., which we classified as highly sensitive species, because of their total absence in areas of greater environmental stress

In summary, given the tolerance shown by various species to diverse environmental factors, it seems clear that the study of sponge communities from a qualitative (composition) and semi-quantitative (relative abundance) point of view contributes to a more exact evaluation of the environment, and we share the opinion of Manus \& Pauly (1990), who consider that ecological stress cannot be inferred from diversity alone; however, we do believe that changes in the structure of the community can be used to indicate ecological stress. The almost constant presence of various species in stations subject to either optimum conditions or great environmental stress permits us to deduce their importance as biological indicators, be it of extreme conditions (Cliona celata, C viridis, Stylopus dujardini), or of normal conditions (Reniera mucosa, R. fulva, Phorbas tenacior). As a summary we have categorised in Table 5 the main species studied according to 2 aspects: distribution and relationship to environmental variables.

Acknowledgements. The authors thank Ms Alma Velasco for translating the manuscript. We also thank the enterprises and institutions that are sponsoring the research project 'Estudio biológico de las comunidades bénticas de la Bahía de Algeriras' Compania Española de Pétroleos S.A. (CEPSA), Fundación Sevillana de Electricidad, Excmo. Ayuntamiento de los Barrios and Mancomunidad de Municipios del Campo de Gibraltar, whose support made possible a great part of the fieldwork necessary for this study. We also thank 3 anonymous reviewers for constructive criticism.

\section{LITERATURE CITED}

Alcolado PM (1978) Ecological structure of the sponge fauna in a reef profile of Cuba. In: Lévi C, Boury-Esnault $N$ (eds) Coll Intern CNRS 291, Biologie des Spongiaires, Paris p 297-302

Alcolado PM. Herrera A (1987) Efectos de la contaminación sobre las comunidades de esponjas en el litoral de la Habana. Cuba Rep Inv Inst Oceanol Acad Ciencias de Cuba 68:1-23

Bailey-Brock J (1979) Sediment trapping by chaetopterid polychaetes on a Hawaiian fringing reef. J Mar Res 37(4): $643-656$

Bakus GJ (1967) Sedimentation and benthic invertebrates of Fanning lsland, Central Pacific. Mar Geol 6:45-51

Bray RJ, Curtis JI (1957) An ordination of the upland forest communities of southern Wisconsin. Ecol Monogr 27: $325-349$

Buizer DAG, Soest RWM (1977) Mycale micracanthoxea nov. spec. (Porifera, Poecilosclerida) from The Netherlands. Neth J Sea Res 11 (3/4):297-304

Carballo JL, Garcia-Gómez JC (1994) The northeastern Atlantic species Mycale micracanthoxea Buiser \& Van Soest 1977 (Porifera, Poncilosclerida) in the Strait of Gibraltar (southern Spain). Beaufortia 44(2):11-16

Carballo JL, Sanchez-Moyano JE, Garcla-Gómez JC (1994) Taxonomical and ecological remarks on boring sponges (Clionidae) from the Straits of Gibraltar (southern Spain): tentative bioindicators? Zool J Linn Soc 112:407-424

Clarke KR (1993) Non-parametric multivariate analyses of changes in community structure. Aust J Ecol 18:117-143

Clarke KR, Ainsworth M (1993) A method of linking multivariate community structure to environmental variables. Mar Ecol Prog Ser 92:205-219

Field JG, Clarke KR, Warwick M (1982) A practical strategy for analysing multispecies distribution pattern.s. Mar Ecol. Prog Ser 8:37-52

Gambi MC, Buia MC, Casola E, Scardı M (1989) Estimate of water movement in Posidonia oceanica beds. In: Boud-

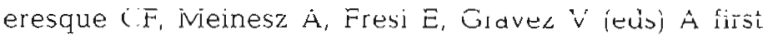
approach. International Workshop of Posidonia Beds France 2:101-1.12

Hawkins SJ, Proud SV, Spence SK, Southward AJ (1994) 
From the individual to the community and beyond: water quality, stress indicators and key species in coastal ecosystems. In: Sutcliffe DW (ed) Water quality and stress indicators in marine and freshwater systems: linking levels of organisation. Freshwater Biological Association Special Publications, UK, p 35-62

Manus JW, Pauly D (1990) Measuring ecological stress: variations on a theme by R.M. Warwick. Mar Biol 106:305-308

Margalef R (1968) Perspectives in ecological theory. University of Chicago Press, Chicago

Moore PG (1972) Particulate matter in the sublittoral zone of an exposed coast and its ecological significance with special references to the fauna inhabiting kelp holdfasts. J Exp Mar Biol Ecol 10:59-80

Muller P (1974) Introducción a la zoogeografía. Ed. Blume, Barcelona

Muricy G (1989) Sponges as pollution-biomonitors at Arraial do Cabo, Southeastern Brazil. Rev Brasil Biol 49(2): $347-354$

Muricy G (1991) Structure des peuplements de spongiaires autour de l'égout de Cortiou (Marseille, France). Vie Milieu 41(4):205-221

Muricy G, Hajdu E, Custodio M, Klautau M, Russo C, Peixinho S (1991) Sponge distribution at Arraial do Cabo, S.E. Brazil. Proc VII Symp Coast Ocean Manag ASCE Publs 2: 1183-1196

Reiswig HM (1971) Particle feeding in natural populations of three marine demosponges. Biol Bull Mar Biol Lab Woods Hole 141:568-591

Sará M (1974) Spongiaires. Catalogue des principales salis-

This article was submitted to the editor sures marines. Comité Intern Perm Rech Préserv Matériaux en Milieu Marin 5:1-42

Sará M. Vacelet J (1973) Ecologie des démosponges. In: Grassé PP (ed) Traité de zoologie Masson et Cie, Paris

Sneath PHA, Sokal RR (1973) Numerical taxonomy. The principles and practique of numerical classification. WH Freeman and Company, San Francisco

Strickland JDH, Parsons TR (1960) A manual of seawater analysis. Bull Fish Res Bd Can 122:1-172

Vacelet J (1978) La place des spongiaires dans les écosystèmes trophıques marins. In: Lévi $\mathrm{C}$, Boury-Esnault $\mathrm{N}$ (eds) Biologie des spongiaires. Coll Intern CNRS 291, Paris, p 259-270

Wait C, Suárez Castaño M, Muñoz Leyva JA (1990) Balance de materia contaminante a la Bahı de Algeciras. Sem Qui Mar 5:229-241

Wilkinson CR, Cheshire AC (1989) Patterns in the distribution of sponge populations across the central Great Barrier Reef. Coral Reefs 8:127-134

Wilkinson CR, Vacelet J (1979) Transplantation of marine sponges to different conditions of light and currents. J Exp Mar Biol Ecol 37:91-104

Wilson MV Shmida A (1984) Measuring beta diversity with presence-absence data. J Ecol 72:1055-1064

Wright JF, Furse MT, Armitage PD (1994) Use of macroinvertebrate communities to detect environmental stress in running waters. In: Sutcliffe DW (ed) Water quality and stress indicators in marine and freshwater systems: linking levels of organisation Freshwater Biological Association Special Publications, UK, p 15-34

Manuscript first received: August 7, 1995

Revised version accepted: November 2, 1995 